\title{
Studies of Genetic Parameters for Yield and Yield Attributing Traits of Kodo Millet (Paspalum scrobiculatum L.)
}

\author{
Jyoti Thakur*, R.R. Kanwar, Prafull Kumar, J.L. Salam and Sonali Kar \\ Department of Genetics and Plant Breeding, S. G. College of Agriculture and Research \\ Station, Jagdalpur - 404 001, Chhattisgarh, India \\ *Corresponding author
}

\section{A B S T R A C T}

The present study on "Studies of genetic parameters for yield and yield attributing traits of kodo millet (Paspalum scrobiculatum L.)" was carried out at Instructional cum Research

\section{Keywords}

Kodo millet, Paspalum scrobiculatum, Heritability, Variability, GCV, PCV, Genetic advance

Article Info

Accepted:

04 August 2018

Available Online:

10 September 2018
Farm of S.G. College of Agriculture and Research Station Kumhrawand, Jagdalpur, Chhattisgarh. Thirty three kodo millet (Paspalum scrobiculatum L.) genotypes were evaluated to measure genetic parameters i.e. genetic variability, heritability, genetic advance as percent of mean for nine quantitative traits. The phenotypic coefficient of variance (PCV) slightly higher than genotypic coefficient of variance (GCV) for all traits under studied. Among the trait under studied, tiller per plant showed highest PCV and GCV followed by grain yield per plot (g) and fodder yield (g). Higher broad sense heritability was estimate for days to maturity followed by days to flowering, tillers per plant and panicle length. Results revealed high heritability coupled with high genetic advance as percent of mean was higher for tillers per plant followed by panicle length $(\mathrm{cm})$, plant height $(\mathrm{cm})$, fodder yield $(\mathrm{g})$ and test weight $(\mathrm{g})$, these traits were directly selected because they were under the control of additive gene action. High heritability accompanied with high genetic advance as percent of mean was under the control of additive gene action and therefore simple selection is advantage for these traits.

\section{Introduction}

Kodo millet (Paspalum scrobiculatum L.) is a small grained cereal belonging to family Poaceae (Gramineae). It is a tetraploid $(2 n=4 x=40)$ crop species. Kodo millet is grown for its grain and fodder purpose. Kodo millet is also known as varagu, kodo, haraka, arakalu, ditch millet, rice grass, cow grass, native paspalum, or Indian crown grass. It is grown in India, Pakistan, Philippines, Indonesia, Vietnam, Thailand and West Africa (Deshpande et al., 2015). It is widely distributed in damp habitats across the tropics and subtropics of the World. Kodo millet is indigenous to India (De Wet et al., 1983).

In India area of small millet 589.6 (000) ha. With a production of 358.9 (000) metric tons and productivity of $654.9 \mathrm{~kg} / \mathrm{ha}$. (Indian Institute of Millet Research 2014). Kodo millet is gaining importance due to dual reasons like nutritional properties and stress tolerance (Kumar et al., 2016). It provides low priced protein, minerals and vitamins in form of sustainable food (Yadava et al., 2006). The 
millet contains a high proportion of complex carbohydrate and dietary fibre which helps in prevention of constipation and slow release of glucose to the blood stream (Kumar et al., 2016).

Kodo contain water soluble fiber and this property may be utilized for maintaining or lowering blood glucose response among diabetic and cardiovascular disease patients, glycemic load (GL) representing both quality and quantity of carbohydrate in a food and allows comparison of the likely glycemic effect of realistic portion of the different foods and low glycemic index foods like kodo, have been shown to improve the glucose tolerance in both healthy and diabetic subjects (Riccardi et al., 2008).

Systematic breeding efforts in this crop have so far been neglected. For starting any crop improvement work, information about the genetic variability available in the population is a prerequisite. Presence of high variability in the germplasm of this crop offers much scope for its improvement (Subramanian et al., 2010).

Estimation of genetic parameters in the context of trait characterization is an essential component in developing high yielding varieties (Reddey et al., 2013). Genetic variability is a basis for any heritable improvement in crop plants. Variability can be observed through biometric parameters like genotypic coefficient of variation (GCV), phenotypic coefficient of variation (PCV), heritability (broad sense) and genetic advance as percent of mean in respect of nine characters.

\section{Materials and Methods}

The present study was carried out at Research cum Instructional Farm of S.G. College of Agriculture and Research Station
Kumhrawand, Jagdalpur, Chhattisgarh. Jagdalpur is situated in $19^{\circ} 4^{\prime} 0^{\prime \prime} \mathrm{N}$ and $82^{\circ} 2^{\prime} 0^{\prime \prime}$ E. The city is nestled on the Bastar Plateau and is positioned at a height of around 552 meters from the mean sea level. The investigation was conducted during kharif 2017-18 in randomized block design. With 80 germplasm of kodo millet in which 33 were selected for genetic analysis presented in table 1. The crop was sown on plot size $2.25 \mathrm{~m} \times 3 \mathrm{~m}$ and the spacing of $22 \mathrm{~cm}$ within rows and 10 $\mathrm{cm}$ between the plants. The regional crop production practices were followed.

Observations were recorded on randomly chosen five plants from each entry for 7 quantitative traits viz. plant height, number of tillers per plant, number of panicles per plant, panicle length, grain yield, fodder yield and test weight from both replication, except flowering and maturity, they were recorded on plot basis. Broad sense was categorized as the method suggested by Robinson (1966) low $(<50 \%)$, moderate $(50-70 \%)$ and high $(>70$ $\%)$. The magnitude of genetic advance as percentage of mean easily categorized as high $(>20 \%)$, moderate $(20-10 \%)$ and low $(<10 \%)$ as suggested by Johnson et al., (1955) using mean square values from the ANOVA table.

Observations were recorded on competitive and randomly chosen five plants from each genotype and from both replication, except flowering and maturity, they were recorded on plot basis. Average of the data from the sampled plants in respect of different quantitative characters was used for various statistical analyses.

\section{Estimation of genetic parameters}

The mean data of all characters was subjected to ANOVA and ANCOVA analyses to get the estimates of mean sum of squares and mean sum of products and these were utilized for calculation of following parameters. 


\section{Genotypic and phenotypic coefficient of variation}

\section{Variance}

The genotypic and phenotypic variances were calculated as per the formulae proposed by Burton (1952)

Genotypic variance $\sigma g^{2}=$

Number of replications

MSS due to genotypes - MSS due to error

Phenotypic variance $\sigma \mathrm{p}^{2}=\sigma \mathrm{g}^{2}+\sigma \mathrm{e}^{2}$

$\sigma \mathrm{g}^{2}=$ Genotypic variance

$\sigma \mathrm{e}^{2}=$ Error variance

The genotypic (GCV) and phenotypic (PCV) coefficient of variation was calculated by the formulae given by Burton (1952).

$\operatorname{GCV}(\%)=\frac{\sigma g}{\mathrm{X}}$

$\operatorname{PCV}(\%)=\frac{\sigma p}{X} \times 100$

Where,

$\sigma g, \quad \sigma p$ and $\bar{x}$ were genotypic standard deviation, phenotypic standard deviation and general mean of the character, respectively.

Categorization of the range of variation was done as proposed by Sivasubramanian and Madhavamenon (1973)

Less than $10 \%$ - Low

$10-20 \%$ - Moderate

More than 20\% - High

\section{Broad sense heritability}

Heritability in broad sense refers to the proportion of genotypic variance to the total variance of the population. Heritability in broad sense [h2 (b)] was calculated by the formula given by Hanson et al., (1956).

Broad sense heritability $=\frac{\sigma^{2} g}{\sigma^{2} p}$

Where,

$\sigma^{2} \mathrm{~g}=$ Genotypic variance

$\sigma^{2} \mathrm{p}=$ Phenotypic variance

As suggested by Johnson et al., (1955), heritability estimates were categorized as

Less than $30 \%$ - Low

$30-60 \%$ - Moderate

More than $60 \%$ - High

\section{Genetic advance}

Genetic advance refers to the expected genetic gain in the next generation by selecting the superior individuals under certain amount of selection pressure. From the heritability estimates, the genetic advance was estimated by the following formula given by Johnson et al., (1955).

$\mathrm{GA}=\mathrm{k} \sigma \mathrm{p} \mathrm{H}$

Where,

$\mathrm{GA}=$ Genetic advance

$\sigma p=$ Phenotypic standard deviation

$\mathrm{H}=$ Heritability (broad sense)

$\mathrm{K}=$ Selection differential at $5 \%$ selection intensity 
Genetic advance as percent of mean (GA as percent mean)

Genetic advance as percent of mean was calculated as per the formula.

GA as percent of mean $=\frac{\text { GA }}{----} \times 100$

Where,

$\mathrm{GA}=$ Genetic advance

$\mathrm{X}=$ Grand mean of the character

The range of genetic advance as percent of mean was classified as suggested by Johnson et al., (1955).

Less than $10 \%$ - Low

$10-20 \%$ - Moderate

More than 20\% - High

\section{Results and Discussion}

Genetic variability represents the genetic differences within or between populations. Several possible factors, including gene flow due to population migration, homologous recombination or crossing over during meiosis, polyploidy and mutations, might contribute to the genetic variability in the population. The recording of means, range, co-efficient of variation, heritability and genetic advance as percent of mean are presented in Table 2.

Genetic variability is a basis for any heritable improvement in crop plants. Additive genetic variation is heritable portion of the total variation in response to selection and helps in arriving at precise conclusion about the true breeding value of the genotype (John 2017).Variability can be observed through biometric parameters like genotypic coefficient of variation (GCV), phenotypic coefficient of variation (PCV), heritability (broad sense) and genetic advance as percent of mean in respect of nine characters. The trait studied in this investigation showed low, moderate and high GCV and PCV values. The estimation of phenotypic coefficient of variation (PCV) were higher than the genotypic coefficient of variation (GCV) for all the characters this founding is confirmed by Sumathi et al., (2010) in pearl millet, Shinde et al., (2014) and John (2017) in finger millet. The genotypic coefficient of variance was smaller than phenotypic coefficient of variance; it showed that environment did exert masking influence on the expression of genetic variability (Sao et al., 2017b).

Among the trait under studied, tiller per plant showed highest PCV (31.31) and GCV (29.18). These finding are in conformity with those of Salini et al., (2010) for high GCV, Ganapathy et al., (2011) and Yogesesh et al., (2015) for high GCV and PCV. The lowest PCV and GCV were seen for days to 50\% flowering i.e. 9.03 and 8.89 respectively indicated less variation among genotypes under studied. This founding is conformity with Nirmalakumari (2010) for low GCV and PCV and Salini et al., (2010) for low GCV. The difference between genotypic coefficient of variation and phenotypic coefficient of variation was low, showing less variation between genotypes or less influence of environment in the expression of this character. The genotypic coefficient of variation and phenotypic coefficient of variation for plant height was moderate i.e. $13.74 \%$ and $15.47 \%$ respectively. This finding is conformity with those of John (2007) and Dhamdhere et al., (2011) for moderate PCV in finger millet. The character showed moderate genotypic coefficient of variation indicating good scope for selection (Kumari and Singh, 2015). Days to maturity showed lowest PCV and GCV $(9.0 \%, 9.1 \%)$. This finding is conformity with Chaurasiya (2014) and 
Reddey et al., (2013). The phenotypic coefficient of variation estimates in panicle per plant was moderate i.e. $15.11 \%$ and the genotypic coefficient of variation for this trait was low i.e. $9.91 \%$, indicating less variation. Genotypic and phenotypic coefficient of variation for panicle length was moderate i.e. $14.26 \%$ and $15.61 \%$. This founding is conformity with Ganapathy et al., (2011). The genotypic and phenotypic coefficient of variation estimates in days to maturity was low i.e. $9.03 \%$ and $9.10 \%$ respectively. For grain yield genotypic and phenotypic coefficient of variation was high i.e. $19.08 \%$ and $25.79 \%$ respectively. This finding is conformity with Salini et al., (2010), Anuradha et al., (2017) and Sao et al., (2017 b) in kodo millet. Higher difference in values of GCV and PCV revealed that variation is not only due to genotypes but also due to influence of environment and therefore selection can be misleading (Das, 2013).

Fodder yield exhibited genotypic and phenotypic coefficient of variation was high (20.50\% and 22.94\%). Similar result was reported by Sabiel et al., (2014) for high GCV and Sao et al., (2017 b) for high GCV and PCV. Test weight exhibited moderate value for GCV and PCV $11.16 \%$ and $12.42 \%$ respectively. The moderate value for these parameters indicated lesser amount of variation, therefore minimum scope for improvement under direct selection for these characters. The result for panicle length and test weight showed that the traits are less influenced by the environment due to less difference between the genotypic and phenotypic coefficient of variation for these traits. On the contrary, the magnitude of phenotypic coefficient of variation was high as compared to genotypic coefficient of variation for the plant height, tillers per plant, grain yield per plot, fodder yield per plot indicating the role of environmental variance in expression of characters. The magnitude of genetic variability is the possibility of crop improvement. The genotypic components being the heritable part of total variability, its magnitude for yield and its components characters influence the selection strategies to be adopted by the breeder (John, 2017).

Heritability is a measure of the extent of phenotypic variation caused by the action of genes. For making effective improvement in the character for which selection is practiced, heritability has been adopted by large number of workers as a reliable indicator (Chaurasiya, 2014). Heritability helps in distinguish the similarities between parents and their offspring while genetic advance provides the knowledge about expect gain for a particular trait after selection. High heritability coupled with high genetic advance is said to be governed by additive gene action indicating direct selection for trait. Yet, high heritability with low genetic advance is the result of nonadditive gene action and selection for such trait not be rewarding (John 2007). The coefficient of variation reveals the extent of variability, present for different characters but it does not indicate the heritable portion of the variability, it is essential to know the heritability estimates of different attributes (Jyothsna et al., 2016). Heritability estimations are given in Table 2. An attempt has been made in the present investigation to estimate heritability in broad sense and categorized as low $(<50 \%)$, moderate $(50-70$ $\%)$ and high $(>70 \%)$ as suggested by Robinson (1966). The magnitude of genetic advance as percentage of mean easily categorized as high $(>20 \%)$, moderate (20$10 \%)$ and low $(<10 \%)$ as suggested by Johnson et al., (1955). Higher broad sense heritability was estimate for days to maturity $(98.40 \%)$ followed by days to flowering (96.90\%), tillers per plant $(86.90 \%)$, panicle length $(83.40 \%)$. The lowest heritability was estimate for panicle per plant (43.10\%) followed by grain yield per plot (54.80\%). 
Table.1 List of selected 33 genotypes of kodo millet for genetic analysis

\begin{tabular}{|l|l|l|l|l|l|}
\hline S.N. & $\begin{array}{l}\text { Genotype } \\
\text { name }\end{array}$ & S.N. & $\begin{array}{l}\text { Genotype } \\
\text { name }\end{array}$ & S.N. & $\begin{array}{l}\text { Genotype } \\
\text { name }\end{array}$ \\
\hline $\mathbf{1}$ & BK-19 & 12 & BK-48 & 23 & BK-6 \\
\hline $\mathbf{2}$ & BK-20 & 13 & BK-49 & 24 & BK-7 \\
\hline $\mathbf{3}$ & BK-21 & 14 & BK-50 & 25 & BK-8 \\
\hline $\mathbf{4}$ & BK-34 & 15 & BK-64 & 26 & BK-9 \\
\hline $\mathbf{5}$ & BK-35 & 16 & BK-81 & 27 & BK-10 \\
\hline $\mathbf{6}$ & BK-36 & 17 & PCGK-8 & 28 & BK-11 \\
\hline $\mathbf{7}$ & BK-38 & 18 & PCGK-12 & 29 & BK-12 \\
\hline $\mathbf{8}$ & BK-42 & 19 & BK-1 & 30 & BK-13 \\
\hline $\mathbf{9}$ & BK-43 & 20 & BK-2 & 31 & BK-14 \\
\hline $\mathbf{1 0}$ & BK-45 & 21 & BK-3 & 32 & IK-01* \\
\hline $\mathbf{1 1}$ & BK-46 & 22 & BK-5 & 33 & IK-02* \\
\hline
\end{tabular}

Table.2 Genetic parameters for seed yield and its attributing traits in kodo millet

\begin{tabular}{|c|c|c|c|c|c|c|c|c|c|c|}
\hline \multicolumn{2}{|c|}{ Characters } & Plant & Tillers/ & Panicles & Panicle & DAS to & DAS to & Grain & Fodder & Test \\
\hline \multirow[t]{2}{*}{ Range } & Max & 56.00 & 7.00 & 4.00 & 8.50 & 86.00 & 124.00 & 2.00 & 17.15 & 10.30 \\
\hline & Min & 33.50 & 2.50 & 2.00 & 4.55 & 60.50 & 91.00 & 0.90 & 8.20 & 6.30 \\
\hline GCV & & 13.75 & 29.19 & 9.92 & 14.26 & 8.89 & 9.03 & 19.09 & 20.51 & 11.16 \\
\hline PCV & & 15.48 & 31.31 & 15.11 & 15.61 & 9.03 & 9.11 & 25.79 & 22.95 & 12.43 \\
\hline $\mathrm{h}^{2} \mathrm{bs}$ & & 0.79 & 0.87 & 0.43 & 0.83 & 0.97 & 0.98 & 0.55 & 0.80 & 0.81 \\
\hline GA & & 11.38 & 2.10 & 0.39 & 1.74 & 12.74 & 19.92 & 0.41 & 4.47 & 1.71 \\
\hline GA \% of Mean & & 25.15 & 56.05 & 13.41 & 26.83 & 18.02 & 18.45 & 29.10 & 37.75 & 20.64 \\
\hline Mean & & 45.24 & 3.74 & 2.89 & 6.48 & 70.70 & 107.95 & 1.40 & 11.83 & 8.27 \\
\hline
\end{tabular}

The character days to maturity (19.91) exhibited higher genetic advance followed by days to $50 \%$ flowering (12.74), plant height (11.37) and the character panicles per plant (0.38) showed lowest genetic advance followed by grain yield per plot (0.46), test weight (1.70) and panicle length (1.73). The genetic advance expressed as percentage of mean was highest for tillers per plant (56.04) followed by fodder yield (37.75), grain yield (29.10), and panicle length (26.83). The character panicles per plant (13.40) showed lowest genetic advance as percent of mean followed by days to $50 \%$ flowering (18.02) and days to maturity (18.45). The observed heritability estimate for tillers per plant was high (86.90\%) with high genetic advance as percent of mean (56.04). In accordance to report of John (2006), Ganapathy et al., (2011) and Priyadarshini et al., (2011) in finger millet. High heritability coupled with high genetic advance as percent of mean for this character indicated the predominance of additive gene action and selection may be rewarding in improving this character. The panicle per plant possessed low heritability $(43.10 \%)$ and moderate genetic advance (13.40). Sabeil et al., (2014) reported low 
heritability for this trait while genetic advance was also low in pearl millet. Low heritability coupled with moderate genetic advance as percent of mean indicated the predominance of non-additive gene action in the inheritance of this trait and desired result may not be obtained by direct selection and selection should be practiced at later segregating generation. The heritability estimate for panicle length was high heritability $(83.40 \%)$ with high genetic advance (26.83). high heritability accompanied with high genetic advance as percent of mean for this trait (Bezaweletaw et al., 2006; Govindrajan et al., 2010). High heritability with high genetic advance indicated the predominance of additive gene action and therefore improving can be anticipated by simple selection. The heritability estimate for days to $50 \%$ flowering was high $(96.90 \%)$ with moderate genetic advance as percent of mean (18.02). Moderate genetic advance as percent of mean for this trait in proso millet and Chaurasiya (2014) found high heritability for this trait while genetic advance percent of mean was low. Days to maturity showed heritability which was high $(98.40 \%)$ with moderate genetic advance (18.45). Chaurasiya (2014) reported high heritability for this character. High heritability coupled with moderate genetic advance as percent of mean indicated that this trait appear to be under the control of both additive and non-additive gene action and selection might be postponed to latter generation to harness the non-additive gene action (Bezaweletaw et al., 2006). The heritability estimate for plant height was high (78.90\%) with high genetic advance (25.14). this founding is conformity with Ganapathy et al., (2011) and Priyadarshini et al., (2011) in finger millet. High heritability coupled with high genetic advance as percent of mean for this trait indicated the predominance of additive gene action hence improvement can be anticipated by simple selection (Shinde et al., 2014, Kumari and Singh 2015).Grain yield per plot showed moderate heritability $(54.80 \%)$ with high genetic advance (29.10). Govindrajan et al., (2010) and Nirmalakumari (2010) reported for this parameter high heritability coupled with high genetic advance and Kadam et al., (2010) for high variability and genetic advance. Moderate heritability combine with high genetic advance as percent of mean indicated the predominance of additive and non-additive gene action. The observed heritability estimate for fodder yield per plot was high $(79.90 \%)$ with high genetic advance (37.75). This founding is conformity with Sao et al., (2017). The heritability estimates for test weight was high $(80.60 \%)$ coupled with high genetic advance (20.64). Earlier reported by Auti et al., (2011) high variability for this trait in finger millet and Chaurasiya (2014) reported high GCV and PCV for this trait. High heritability accompanied with high genetic advance as percent of mean was under the control of additive gene action and therefore simple selection is advantage for these traits. Conclusively high values of broad sense heritability coupled with high genetic advance as percent of mean was observed for tillers per plant, panicle length, plant height, fodder yield per plot and for test weight. So these traits were predominantly under the control of additive gene action and they were least influenced by environmental modification i.e. phenotypes were the true representative of their genotypes and selection based on phenotypic performance would be reliable (Singh, 2017). Low heritability with moderate gene action were observed in panicles per plant, low heritability showed that these trait is more influenced by the environment hence not suitable for direct selection. Moderate heritability with high genetic advance were reported in grain yield per plot and high heritability with moderate gene action were recorded for days to $50 \%$ flowering and days to maturity, indicating predominance of both additive and non-additive gene action. It is 
suggested that genetic gain should be considered in conjugation with heritability estimates (Johnson et al., 1955) Genotypic coefficient of variation (GCV) along with heritable estimates would provide a better picture of the amount of genetic advance to be expected by phenotypic selection (Burton 1952). Studied of coefficient of variation showed that the estimation of phenotypic coefficient of variation for all the traits were slightly higher than genotypic coefficient of variation showing that the characters were less influenced by the environment. Hence on the basis of phenotype, selection will be effective for improvement of these characters. Under selection estimates of heritability coupled with genetic advance are more useful in predicting the gain than alone estimates of heritability.

Estimation of phenotypic coefficient of variation for all the traits were slightly higher than genotypic coefficient of variation showing that the characters were less influenced by the environment. Hence on the basis of phenotype, selection will be effective for improvement of these characters. Among the trait under studied, tiller per plant showed highest PCV and GCV followed by grain yield per plot (g) and fodder yield (g). Higher broad sense heritability was estimate for days to maturity followed by days to flowering, tillers per plant and panicle length. High values of broad sense heritability coupled with high genetic advance as percent of mean was observed for tillers per plant, panicle length $(\mathrm{cm})$, plant height $(\mathrm{cm})$, fodder yield per plot and for test weight $(\mathrm{g})$. So these traits were predominantly under the control of additive gene action and they were least influenced by environmental modification. The traits panicles per plant, days to $50 \%$ flowering, days to maturity, grain yield were under the control of both additive and nonadditive gene action and therefore direct selection is un rewarding.

\section{References}

Anonymous. 2014. Department of Agriculture Chhattisgarh. www.agridept.cg.gov.in

Anuradha, N., Patro, T. S. S. K., Divya, M., Sandhya Rani, Y. and Triveni, U. 2017. Genetic variability, heritability and correlation of quantitative traits in little millet genotypes. J. of Pharmacognosy and Phytochemistry 2017; 6(6): 489492.

Autil, S. G., Kazil, T., and Ahire D. D. 2017. Morpho - agronomic diversity in [Eleusine coracana (L.) Gaertn] landraces from Maharashtra State (India). J. of Sci. Agri. 1: 54-61.

Bezaweletaw, K., Sripichitt, P., Wongyai, W.. And Hongtrakul, V. 2006. Genetic variation, heritability and path-analysis in Ethiopian finger millet [Eleusine coracana (L.) Gaertn] landraces. Kasetsart J. (Nat. Sci.) 40: 322 - 334.

Burton G. W. 1952. Quantitative inheritance in grasses. Proc. $6^{\text {th }}$ Intr. Grassland Cong., 1:227-283.

Chaurasiya, V. (2014). Genetic variability. Association and path coefficient analysis for grain yield and its components in kodo millet (Paspalum scrobiculatum L.) Thesis. JNKVV, Jabalpur. P. 38-44.

Das, R. 2013. Genetic divergence studies in finger millet (Eleusine coracana (L.) Gaertn) germplasm. MSc Thesis, Acharya N. G. Ranga Agricultural University, Hyderabad. P 73-75.

Deshpandey, S S., Mohapatra, D., Tripathi, M K., and Sadvatha, R H. 2015. Kodo Millet-Nutritional Value and Utilization in Indian Foods. ICAR-Central Institute of Agricultural Engineering, Nabibagh, Berasia Road, Bhopal (M.P.), India. JOURNAL OF GRAIN Processing and Storage J. homepage: www.jakraya. com/journal/jgps 
De-Wet J M J, Prasada Rao K E, Mengesha M H and Brink D E. 1983. Diversity in kodo millet, Paspalum scrobiculatum. Economic Botany 37: 159-163.

Ganapathy, S., Nirmalakumari, A. and Muthiah A. R.2011. Genetic variability and inter relationship analyses for economic traits in finger millet germplasm. World J. of Agric. Sci., 7(2): 185-188.

Govindraj, M., Shanmugasundaram, P., Sumathi, P. and Muthiah, A. R. 2010. Simple, rapid and cost effective screening method for drought resistant breeding in pearl millet. Electronic J. of Plant Breeding, 1(4): 590-596.

John, S. 2017. Morphological characterization and genetic analysis of finger millet (Eleusine coracana L.) genotypes for rainfed agriculture. Thesis. IGKV, Raipur. P. 48-99.

Johnson, H. W., Robinson, H. F. and Comstock, R. E. 1955. Estimation of genetic variability and environmental variability in soybean. Agron, J. 47: 314-318.

Kadam, D. D., Nigade, R. D. Karad, S. R. 2010. Study of variation and selection parameters in ragi genotypes (Eleusine coracana). Int. J. of Agric. sci., 6(2): 383-385.

Kumar, P., Sao, A., Thakur, A. K., Singh, D.P. 2016 (a). Determining genetic architecture of upland rice (Oryza sativa L.) genotypes under suboptimal rainfed ecosystem. Indian J. of Ecology, 43(1): 174-177.

Kumar, P., Sao, A., Thakur, A. K., Yadav, S. C., and Sahu, P. 2017. Resourceful Photosynthesis System and Stem Reserve Accumulation Plays Decisive Role in Grain Yield of Kodo Millet (Paspalum scrobiculatum) Int. J. Pure App. Biosci. 5 (2): 420-426.

Kumar, Prafull, Sao, A., Thakur, A.K., Netam, R.S. and Sahu, P., 2016 (b)
Kodo millet (Paspalum scrobiculatum) for climate change laid agriculture. In proceedings of brainstorming workshop and two days National seminar on emerging technologies for enhancing water productivity held at IGKV Raipur, India in November 17-18: pp: 93-94.

Kumari, saundarya and Singh, Satish Kumar. 2015. Assesment of genetic diversity in promising finger millet [Eleusine coracana (L.) Gaertn] genotypes. Int. Quartly, J. of Life Sci., 10(2): 825-830.

Nirmalakumari, A. and Vetriventhan, M. 2010. Characterization of foxtail millet germplasm collections for yield contributing traits. Elect. J. of Plant Breeding 1(2): 140-147.

Priyadharshini, C., Nirmalakumari, A., John Joel, A. and Raveendran, A. 2011. Genetic variability and trait relationships in finger millet (Eleusine coracana (L.) Gaertn.) hybrids. Madras Agril. J., 98: 18-21.

Reddey, C.V. Chandra Mohan, Reddey P. V.R.M., Munirathnam, P. and Gowda, J.2013. Studies of genetic variability in yield and yield attributing traits of finger millet [eleusine coracana (L.) Gaertn]. Indian J. Agric. Res.., 47 (6): $549-552$.

Riccardi, G., Rivelluse, A.A. and Giacco, R. 2008 Role of glycemic index and glycemic load in the healthy state, in prediabetics and in diabetes. American J. of Clinical Nutrition, 87: 269S-74S.

Robinson, H.F. (1966). Quantitative genetics in relation to breeding on the central of Mendalism. Indian J. Genet., 26A: 171187.

Sabiel, Salih A. I., Ismail, Mohamed I., Abdalla, Elgailani., Osman, Khalid A., Ali Adam M. 2014. Genetic variation among Pearl millet genotypes for yield and its components in semi-arid zone 
Sudan. Int. J. of Agric. and Crop Sci., $822-826$

Salini, K., Nirmalakumari, A., Muthiah, A. R. and Senthil, N. 2010. Evaluation of proso millet (Panicum miliaceum L.) germplasm collections. Elect. J. of Plant Breeding 1(4): 489-499.

Sao, A., Singh, P., Kumar, P., and Pradhan, A. 2017. Estimates of genetic parameters for yield and contributing traits in kodo millet (Paspalum scrobiculatum L.). Res. J. of Agri. Sci. 8(1): 120-122.

Singh, S., (2017). Genetic divergence analysis in indigenous genotypes of cowpea (Vigna unguiculata L. walp) of Bastar. Thesis, IGKV, Raipur. Pp. 62.

Sivasubramanian, S. and Madhava, M. 1973. Genotypic and phenotypic variability in rice. Madras Agriculture Journal 60: 1093-1096.

Subramanian, A., Nirmalakumari, A., and Veerabadhiran, P. 2010. Trait based selection of superior kodo millet (Paspalum scrobiculatum L.) genotype. Elect. J. of Plant Breeding 1(4): 852855.

Sumathi, P., Madineni, S. and Veer, badhiran. (2010). Genetic variability for different biometrical traits in pearl millet genotypes (Pennisetum glaucum L. R. BR.). Elect. J. of Plant Breeding, 1(4): 437-440.

Yadava, H. S., Jain, A. K., 2006. Advances in kodo millet research. New Delhi Directorate of Information and Publications of Agriculture, Indian Council of Agric. Res.,

Yogeesh, L. N., Anand Shankar, K., Prashant, S. M., Lokesh, G. Y. 2015. Genetic variation and morphological diversity in foxtail millet. Int. J. of Sci., Environ. Tech., Vol. 4, 1496-1502.

\section{How to cite this article:}

Jyoti Thakur, R.R. Kanwar, Prafull Kumar, J.L. Salam and Sonali Kar. 2018. Studies of Genetic Parameters for Yield and Yield Attributing Traits of Kodo Millet (Paspalum scrobiculatum L.). Int.J.Curr.Microbiol.App.Sci. 7(09): 278-287. doi: https://doi.org/10.20546/ijcmas.2018.709.035 